This is the accepted version of the following article: GERIČ STARE, Barbara, STRAJNAR, Polona, ŠIRCA, Saša, SUSIČ, Nik, UREK, Gregor. Record of a new location for tropical root knot nematode Meloidogyne luci in Slovenia. Bulletin OEPP, EPPO Bulletin, April 2018, vol. 48, no. 1, pp. 135-137, which has been published in final form at [https://onlinelibrary.wiley.com/doi/abs/10.1111/epp.12443]. This article may be used for non-commercial purposes in accordance with the Wiley Self-Archiving Policy [https://authorservices.wiley.com/author-resources/JournalAuthors/licensing-open-access/open-access/self-archiving.html].

\title{
RECORD OF A NEW LOCATION FOR TROPICAL ROOT KNOT NEMATODE Meloidogyne luci IN SLOVENIA
}

\section{Barbara GERIČ STARE, Polona STRAJNAR, Saša ŠIRCA, Nik SUSIČ, Gregor UREK}

Agricultural Institute of Slovenia, Plant Protection Department, Hacquetova ulica 17, 1001 Ljubljana, Slovenia.

Running head: New location for Meloidogyne luci in Slovenia

Corresponding author: Barbara Gerič Stare

Fax number: +38612805262

E-mail addresses of all authors: barbara.geric@kis.si, polona.strajnar@kis.si, sasa.sirca@kis.si,nik.susic@kis.si, gregor.urek@kis.si

\begin{abstract}
The plant parasitic nematode Meloidogyne ethiopica Whitehead has been reported from several European countries, including Slovenia, where it was first found in 2003. However, the description in 2014 of a new sister species, Meloidogyne luci Carneiro et al., 2014, called for the reclassification of all European and Turkish populations of M. ethiopica reported up to this date as $M$. luci. Both species $M$. ethiopica and $M$. luci have a very wide host range of monocotyledons and dicotyledons. They are pests of important agricultural crops such as maize, potatoes and variety of vegetables, and represent a serious threat for agricultural production in greenhouses as well as in the open fields in many EPPO countries. This paper reports a new location of the tropical root knot nematode species $M$. luci found in Slovenia in 2015.
\end{abstract}


Signalement du nématode a galles tropical Meloidogyne luci dans un nouveau site en Slovénie

La présence de nématode parasite des végétaux Meloidogyne ethiopica Whitehead a été constatée dans plusieurs pays européens, y compris en Slovénie où il a été découvert pour la première fois en 2003. Cependant, la description en 2014 d'une nouvelle espèce proche, Meloidogyne luci Carneiro et al., 2014, a nécessité la reclassification de toutes les populations européennes et turques de $M$. thiopica signalées jusqu'alors comme étant $M$. luci.Les espèces M. ethiopica et M. luci ont toutes deux une très large gamme d'hôtes d'espèces monocotylédones et dicotylédones. Il s'agit d'organismes nuisibles d'importantes cultures telles que le maïs, les pommes de terre et différents légumes. Ils représentent une menace sérieuse pour la production agricole sous serre ainsi qu'en plein champ dans de nombreux pays membres de l'OEPP. Cet article signale la présence du nématode à galles $M$. luci dans un nouveau site en Slovénie en 2015.

\section{галловой нематоды Meloidogyne luci в Словении}

Присутствие паразитирующей на растениях нематоды Meloidogyne ethiopica (Whitehead) было зарегистрировано в нескольких европейских странах, включая Словению, где она впервые была обнаружена в 2003 году. Однако описание в 2014 году новой сестринской группы Meloidogyne luci (Carneiro et al., 2014), привело к реклассификации всех европейских и турецких популяций M. etiopica отмечавшихся до этого как M. luci. Оба вида, M. etiopica и M. lисі, имеют очень широкий круг однодольных и двудольных хозяев. Они вредят важным сельскохозяйственным культурам, таким как кукуруза, картофель и различные овощи, и представляют серьезную угрозу для сельскохозяйственного производства, как в теплицах, так и в открытом грунте во многих странах ЕОКЗР. В этой статье сообщается о новом местонахождении тропической галловой нематоды $M$. luci, обнаруженной в Словении в 2015 году.

\section{Introduction}

Meloidogyne ethiopica Whitehead, a tropical group root knot nematode species was recorded in Slovenia for the first time in 2003, on tomato roots from a greenhouse situated in the village of Dornberk (Širca et al., 2004). This was also the first report of this species in 
Europe. All infested plants were destroyed and the nematode pest was eradicated and considered as not established in Slovenia. M. ethiopica was later reported from other EPPO countries: Greece (Conceição et al., 2012), Italy (Maleita et al., 2012) and Turkey (Aydinli et al., 2013). In 2014, M. luci n. sp. Carniero et al., 2014 a new root knot nematode species parasitizing different crops in Brazil, Chile and Iran was described. The species was found to be closely related to $M$. ethiopica. Description of a new sister species, which has slight morphological differences and different esterase isozyme phenotype, called for reexamination of the populations previously identified as M. ethiopica. All populations of $M$. ethiopica from Europe and Turkey reported in the past were recognised as being M. luci (EPPO RS 2016; Janssen et al., 2016; Gerič Stare et al., 2017).

\section{New record of $M$. luci in Slovenia}

During a root knot nematode field survey in Slovenia in 2015 the root knot nematode M. luci was found in a greenhouse in the village Šmartno near Ljubljana. Infested tomato plants showed symptoms of decline, leaf chlorosis and large galls were present on the roots. Nematode infestation was relatively high as more than $80 \%$ of plants were severely infested. Tomato roots were examined and thirty root knot nematode females were isolated for species identification using isozyme esterase and malate dehydrogenase phenotypes analyses. The nematodes were identified as $M$. luci based on L3 esterase phenotype and N1 malate dehydrogenase phenotypes. In addition, a single egg mass was used for DNA isolation and a region of mtDNA, stretching from the gene for cytochrome oxidase subunit II through to a portion of the 16S rRNA gene was amplified, cloned and sequenced. Phylogenetic analysis of mtDNA sequences (acc. nos. LT837518 and LT837519) confirmed species identification of M. luci.

The new location of $M$. luci the Šmartno village is situated approximately $100 \mathrm{~km}$ apart from the 2003 M. luci infestation (identified as M. ethiopica at that time). Strict phytosanitary measures were imposed in the infested greenhouse in 2015 including the use of Dazomet a soil sterilant. All infested plant material from the affected greenhouse was destroyed. However, the eradication program implemented in the past two years has not been successful to date. Therefore only resistant tomato cultivars carrying $M i$ gene and poor- to non-host crops were allowed to be grown in the infested greenhouse. The success of this crop rotation in eliminating the nematode will be assessed in the future.

\section{Potential threat for the EPPO region}


As the climate conditions are favourable for survival of $M$. luci in many regions of EPPO countries (Širca et al., 2017), the authors suspect that this nematode species could already be or become more widespread in Slovenia and possibly in other Mediterranean countries. Meloidogyne luci has a very wide host range of monocotyledons and dicotyledons including important agricultural crops such as maize, potatoes and variety of vegetables (Strajnar et al., 2009; Maleita et al., 2017). The fact that there is no known differential host plant to distinguish between $M$. ethiopica and $M$. luci found so far, suggests that the two species are very closely related (Gerič Stare et al., 2017). Phylogenetic analyses further confirmed a very close relationship between M. ethiopica and M. luci species (Janssen et al., 2016; Gerič Stare et al., 2017). Therefore a serious threat to agriculture is represented by M. ethiopica (Carneiro et al., 2003, 2007, Aballay et al., 2009, Medina et al., 2014) as well as M. luci (Maleita et al., 2017). Meloidogyne luci has already been detected in the open field agricultural production in Europe as it has been found in kiwi and maize production in Greece (Conceição et al., 2012) and potato production in Portugal (Maleita et al., 2017). In addition it has been shown that $M$. luci survives open field winter conditions in continental and sub-Mediterranean climate (Strajnar et al., 2011). The authors anticipate that climate change and increased temperatures may result in significantly greater spread and damage in several agricultural crops in the open field by $M$. luci in the future.

The $M i-1$ resistance gene has been introgressed into many commercial tomato cultivars to control the root knot nematode species $M$. incognita, $M$. javanica and $M$. arenaria. It has also been shown that $M i-1$ prevents the reproduction of $M$. luci (Strajnar \& Širca, 2011). In Turkey $M i-1$ tomato cultivars are widely used to control root knot nematode species including $M$. luci. However, the finding of virulent populations of $M$. luci in Turkey that can reproduce on tomato plants bearing $\mathrm{Mi}-1$ resistance gene adds to the concern about the damage potential of this pest (Aydinli \& Mennan, 2016) which could become an emerging problem for the Mediterranean and other temperate regions in Europe.

\section{References:}

Aballay E, Persson P \& Mårtensson A (2009) [Plant-parasitic nematodes in Chilean vineyards.] Nematropica 39, 85-97.

Aydinli G, Mennan S, Devran Z, Širca S, \& Urek G (2013) [First report of the root-knot nematode Meloidogyne ethiopica on tomato and cucumber in Turkey.] Plant Disease 97, 1262. 
Aydinli G \& Mennan S (2016) [Reproductive ability of Meloidogyne ethiopica populations on tomato plant with Mi resistance gene.] Abstract book of 32nd ESN (European Societety of Nematologists) Symposium. 28th Aug. 1st Sept. 2016, Braga, Portugal, Universidade do Minho, European Society of Nematologists, 2016, p. 86.

Carneiro RMDG, Almeida MRA, Cofcewicz ET, Magunacelaya JC \& Aballay E (2007) [Meloidogyne ethiopica, a major root-knot nematode parasitising Vitis vinifera and other crops in Chile.] Nematology 9, 635-641.

Carneiro RMDG, Correa VR, Almeida MRA, Gomes ACMM, Deimi AM, Castagnone-Sereno P \& Karssen G (2014) [Meloidogyne luci n. sp. (Nematoda: Meloidogynidae), a root-knot nematode parasitising different crops in Brazil, Chile and Iran.] Nematology 16, 289-301.

Carneiro RMDG, Gomes CB, Almeida MRA, Gomes ACMM \& Martins I (2003) [First record of Meloidogyne ethiopica Whitehead, 1968 on kiwi in Brazil and reaction on different plant species.] Nematologia Brassileira 27, 151-158.

Conceição IL, Tzortzakakis EA, Gomes P, Abrantes I \& da Cunha MJ (2012) [Detection of the root-knot nematode Meloidogyne ethiopica in Greece.] European Journal of Plant Pathology 134, 451-457.

EPPO (2016) Previous finding of Meloidogyne ethiopica in Slovenia is now attributed to Meloidogyne luci. EPPO Reporting Service no. 11 - 2016, Num. article: 2016/212

Gerič Stare B, Strajnar P, Susič N, Urek G \& Širca S. (2017) [Reported populations of Meloidogyne ethiopica in Europe identified as Meloidogyne luci.] Plant disease, Posted online ahead of print, https://doi.org/10.1094/PDIS-02-17-0220-RE

Janssen T, Karssen G, Verhaeven M, Coyne D \& Bert W (2016) [Mitochondrial coding genome analysis of tropical root-knot nematodes (Meloidogyne) supports haplotype based diagnostics and reveals evidence of recent reticulate evolution.] Scientific reports 6:22591 DOI: 10.1038/srep22591.

Maleita C M, José Simões M, Egas C, Curtis RHC \& Abrantes IMO (2012) [Biometrical, biochemical, and molecular diagnosis of Portuguese Meloidogyne hispanica isolates.] Plant Disease 96, 865-74.

Maleita C, Esteves I, Cardoso JMS, Cunha MJ, Carneiro RMDG \& Abrantes I (2017) [Meloidogyne luci, a new root-knot nematode parasitising potato in Portugal.] Plant Pathology Accepted manuscript online: DOI: 10.1111/ppa.12755

Medina IL, Coila VHC, Gomes CB, Pereira AS, Nazareno NRX (2014) [Meloidogyne ethiopica report in Parana state, Brazil, and reaction of potato cultivars to root-knot nematode.] Horticultura Brasileira 32, $482-485$ (in Portuguese). 
Strajnar P \& Širca S (2011) [The effect of some insecticides, natural compounds and tomato cv. Venezia with $M i$ gene on the nematode Meloidogyne ethiopica (Nematoda) reproduction.] Acta agriculturae Slovenica 97, 5-10.

Strajnar P, Širca S, Gerič Stare B \& Urek G (2009) [Characterization of the root-knot nematode, Meloidogyne ethiopica Whitehead, 1968, from Slovenia.] Russian Journal of Nematology 17, 135-142.

Strajnar P, Širca S, Knapič M \& Urek G (2011) [Effect of Slovenian climatic conditions on the developmentand survivalof the root-knot nematode Meloidogyne ethiopica.] European Journal of Plant Pathology 129, 81-88.

Širca S, Knapič M, Strajnar P, Gerič Stare B, Susič N \& Urek G (2017) Possible establishment of Meloidogyne ethiopica in Europe on climate data analysis. Abstract book of 69th International Symposium on Crop Protection, May 23, 2017, Ghent, Belgium. Ghent: Ghent University, Faculty of Bioscience Engineering, p. 40.

Širca S, Urek G \& Karssen G (2004) [First report of the root-knot nematode Meloidogyne ethiopica on tomato in Slovenia.] Plant Disease 88: 680.

\section{ACKNOWLEDGEMENTS}

This work was financially supported by the Slovenian Research Agency in the frame of Research Programme Agrobiodiversity (P4-0072) and the Ministry of Agriculture, Forestry and Food of the Republic of Slovenia in the frame of Expert work in the field of plant protection (C2337). 